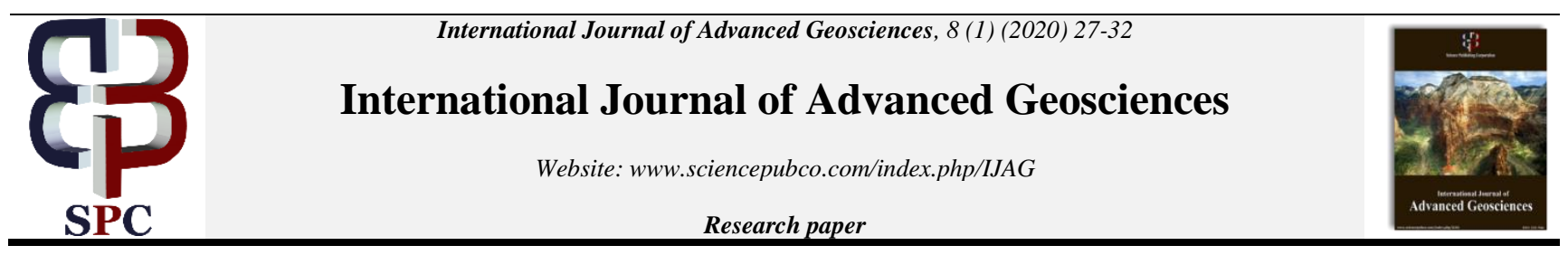

\title{
Illite crystallinity index an indicator of physical weathering of the Sediments of the Tista River, Rangpur, Bangladesh
}

\author{
Sudip Saha $^{1 *}$, A. H. M. Selim Reza ${ }^{1}$, Mrinal Kanti Roy ${ }^{1}$ \\ ${ }^{1}$ Department of Geology and Mining, University of Rajshahi, Rajshahi-6205, Bangladesh \\ *Corresponding author E-mail: sudips_geologist@yahoo.com
}

\begin{abstract}
The Tista River is a tributary of the Brahmaputra River. The deposits that exposed along the both banks of the Tista River are characterized mainly by sand, sand laden with gravel and pebble with minor amounts of silt and clay. The X-ray Diffraction (XRD) of the clay sized sediments of the Tista River reveals that illite (and/or mica), chlorite, kaolinite, quartz and feldspar are the principal mineral constituents. The minor to trace amounts of lavendulan, glauconite lepidolite, enstatite, sekaninaite and ferrierite minerals were identified in the investigated area. Illite constitutes $36 \%$ of the total minerals of the Tista River basin. The values of the illite crystallinity index varies from 0.228 to 0.345 , indicating that the illites are relatively well crystallized and derived from the mechanical weathering of pre-existing rocks. The presence of illite and kaolinite suggests their derivation from the crystalline rocks that contain feldspar and mica, as well as from the preexisting soils and sedimentary rocks. Glauconite forms in the sediments of continental shelf in the marine environment. The accessory minerals like enstatite, sekanianite and ferrierite are derived from basic igneous rocks. The dissolution of copper arsenate mineral, lavendulan might be a source of arsenic in the sediments of the study area.
\end{abstract}

Keywords: Clay; Mechanical Weathering; Illite; XRD and Lavendulan.

\section{Introduction}

Clay mineral assemblage of the Recent Floodplain deposits of the Tista River is significant in understanding the paleoclimatic conditions of the area, types of source rocks, modes of sediment transport, sedimentary environments and post depositional changes experienced by the sediments.

Mica or illite is the dominant constituents of Holocene clay deposits of Bengal Basin (Moslehuddin et al., 1998; Moslehuddin et al., 1999; Pal et al., 2012). Illite (and/or mica) and feldspar are useful to assess the degree of alteration and provide insight about the provenance (Bullock et al., 1985; Delvigne, 1998; Stoops, 2003; Poch et al., 2009; Srivastava et al., 2010; Srivastava et al., 2015). Illite-kaolinite clay mineral assemblage indicates that the sediments were possibly formed under humid, temperate and well drained conditions (Aftabuzzaman et al., 2013).

The Tista River is one of the largest rivers of Rangpur division, Bangladesh. The Tista River originated from the Pauhunri (Teesta Kangse) glacier above 7,068m and flows southwards through gorges and rapids in the Sikkim Himalaya (Meetei et al., 2007; Wiejaczka et al., 2014). The Tista River fed by many tributaries and it has got many distributaries. The total length of the Tista River is $309 \mathrm{~km}$ or $192 \mathrm{miles}$. It drains an area of $12,540 \mathrm{~km}^{2}$. The river is fed by precipitation, melting glacier and snow and groundwater (Mukhopadhyay, 1982). Finally, it falls into the Brahmaputra River, in Bangladesh. The Tista megafan lies in the active tectonic zone of Bangladesh (Sarkar et al., 2009). The Tista megafan is a large triangular sediment body characterized by a radiating drainage pattern and the apex of the megafan coincides with the point of emergence of the Tista River from the mountain belt (Chakraborty and Ghosh, 2010). The deposits that exposed along the both banks of the Tista River are characterized mainly by sand, sand laden with gravel and pebble (Saha et al., 2017).

The study area is located in Rangpur Division that lies in the northern part of Bangladesh. Tectonically the investigated area is situated in the Rangpur Saddle of stable shelf zone of Bengal Basin (Khan and Rahman, 1992; Samsuddin and Abdullah, 1997).

The Tista River draining through the Tista alluvial fan of northwest Bengal Basin which is bounded by the Himalayan Frontal Thrust towards the north (Rahman et al., 2013). The fan has developed by the sediments carried by rivers, which originated from the Himalayas, and draining through Siwalik sediments. The alluvial sediments range from coarser at the north to the finer at the south. The sediments are composed of gravels, sands that are overlain by silty clay deposits. In some places silty clay beds alternate with sands. 


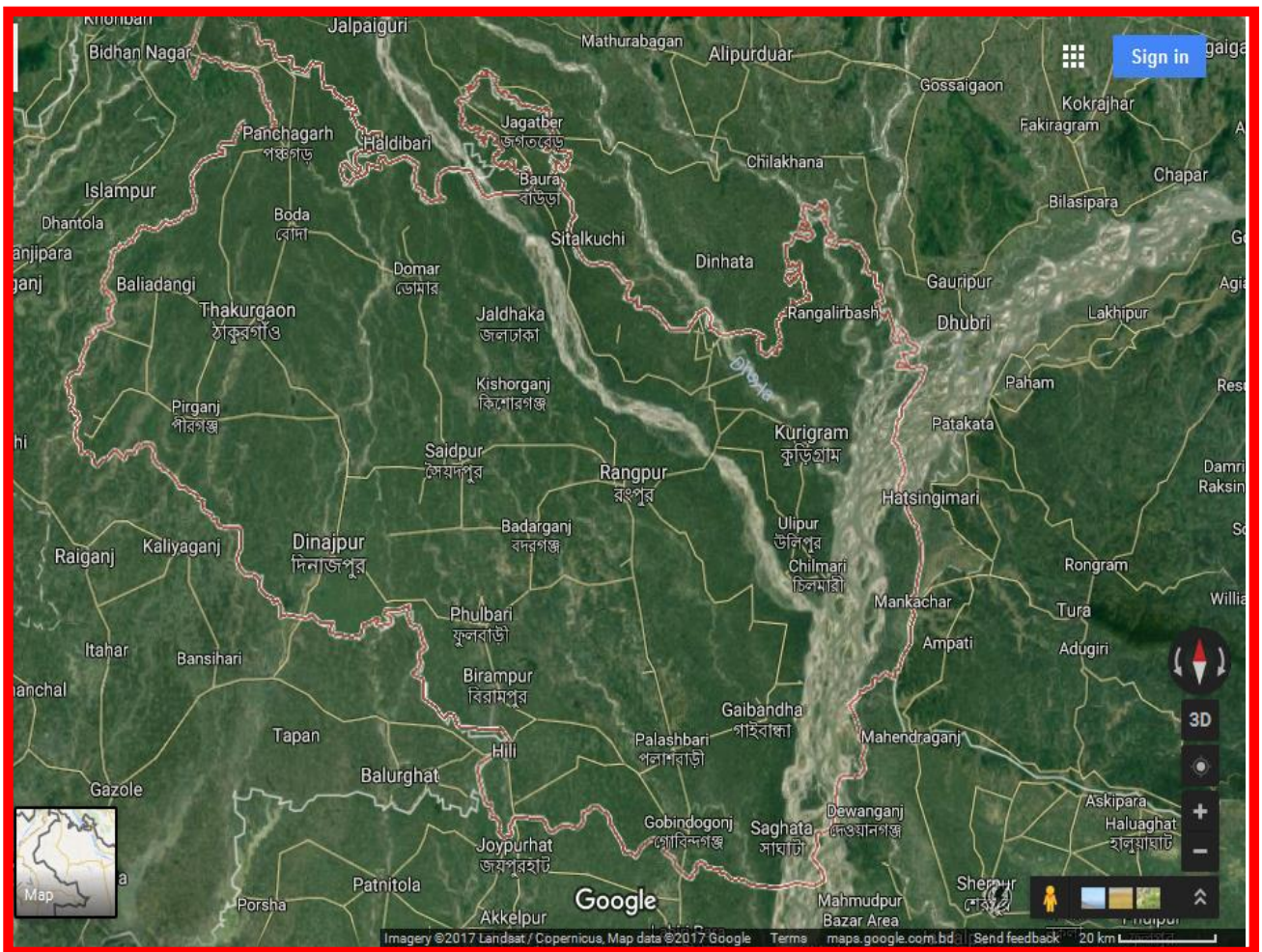

Fig. 1: Map of the Tista River Basin and adjoining areas, Rangpur, Bangladesh.

The present research work aims to determine mineralogical composition of the clay deposits and the provenance the sediments those are exposed along the banks and bars of the Tista River. The clay minerals are formed by the weathering of pre-existing rock material, and therefore can provide information about the weathering history of rocks, and the provenance of the rock. The illite crystallization index is a powerful tool for the origin of illite in clay minerals. A lower crystallinity index value indicates a smaller spacing between illite layers, which in turn indicative of a more crystallized, mechanically sourced illite. A higher crystallinity value indicates less-crystallized illite, and its derivation from diagenesis of primary minerals (Paolo, 2010).

\section{Geology of the study area}

The Tista Floodplain is in the northwestern part of Bangladesh. It is the extension of the Himalayan piedmont plain that slope southward from a height of the $96 \mathrm{~m}$ to $33 \mathrm{~m}$ with a gradient of about $55 \mathrm{~cm} / \mathrm{km}$. The region is covered by the piedmont sand and gravel, which are deposited mainly by the Tista river and its distributaries draining from the Terai area of the foothills of the Himalayas. There was a major shift in the courses of the Tista river in 1887 (GWTF). Tectonically the area lies in the Rangpur saddle.

\section{Methodology}

Clay mineralogical analyses were performed by following Heroy et al. (2003), Tennant (2005) and Saha et al. (2015). Analyses were performed on total sediment and on the $<2 \mu \mathrm{m}$ size fraction. Clay samples were separated by wet sieving and gravity settling techniques. Clays samples were mounted on glass slides in preferred orientation and analyzed using a Rigaku X-ray diffractometer (XRD) with Cu$\mathrm{K} \alpha$ radiation. Clay samples were analyzed in three states in order to best differentiate between different mineral peaks: air dried, after exposure to ethylene glycol and after solvated with dimethyl sulphoxide (DMSO). Peak analyses were performed DMNST version 1.39-1 software from ThermoARL. Peak areas were calculated and calculated relative abundances of minerals. For the purpose of this study, the illite crystallization index (or illite crystallinity) was calculated to determine if the illite found in samples was physical or diagenetic origin. Illite crystallinity was calculated following the method of Kübler described in Jaboyedoff et al. (2001). The Kübler Index (or illite crystallinity index) is defined by the FWHM (full width at half maximum) height of illite $10 \AA$ peaks. These calculations were made using the same XRD data file using the air-dried clay samples. The same computer program was used.

\section{Results}

\subsection{Clay mineral assemblage}

The different clay minerals which were identified in the Holocene sediments of the Tista River include illite or muscovite, chlorite, kaolinite, phengite and glauconite.

Table 1: Relative Abundance of Minerals in Total Sediments in Percent

\begin{tabular}{lllllll}
\hline Sample No & Location & Illite & Chlorite & Kaolinite & Quartz & Feldspar \\
\hline S-4 & Shutibari & 53.68 & 6.03 & 4.68 & 34.58 & 1.03 \\
S-2 & Mohipur & 44.86 & 6.21 & 3.41 & 43.99 & 1.52 \\
S-1 & Pirgacha & 40.16 & 4.94 & 4.30 & 49.84 & 0.76 \\
S-3 & Sundargani & 30.54 & 2.76 & 1.70 & 59.00 & 5.98 \\
S-5 & Chilmari & 10.46 & 1.67 & 0.82 & 83.84 & 3.21 \\
& Average & 35.94 & 4.32 & 2.98 & 54.25 & 2.50 \\
\hline
\end{tabular}




\subsection{Illite}

Illite $\left[\left(\mathrm{K}, \mathrm{H}_{30}\right) \mathrm{Al}_{2}\left(\mathrm{Si}_{3} \mathrm{Al}\right) \mathrm{O}_{10}(\mathrm{OH})_{2} \mathrm{X} \mathrm{H}_{2} \mathrm{O}\right]$ is the dominant clay mineral. The content of illite varies from $10.46 \%$ to $53.68 \%$ with an average value of 36 percent. The basal spacing at $10 \AA$ shows the most dominant peak corresponding to basal reflection along (001) plane. Reflections at $4.99 \AA$ corresponding to (002) are weaker than those at $3.47 \AA$. Organic liquids do not have any effect on the mineral as it contains little or no interlayer water (Chaudhri and Singh, 2012). Illite does not show any change on ethylene glycol treatment.

\subsection{Chlorite}

Chlorite $\left[(\mathrm{Mg}, \mathrm{Fe}, \mathrm{Al})_{6}(\mathrm{Si}, \mathrm{Al})_{4} \mathrm{O}_{10}(\mathrm{OH})_{8}\right]$ comprises 4.32 percent of the total mineral assemblage. The mineral shows strong reflection along (003) plane. The $4.71 \AA$ peak is stronger than $2.82 \AA$. The reflection along (001) is poor. The peak of the mineral which consists of an octahedral layer sandwiched between tetrahedral layer and a single octahedral layer repeating on c, does not show any change after ethylene glycol treatment.

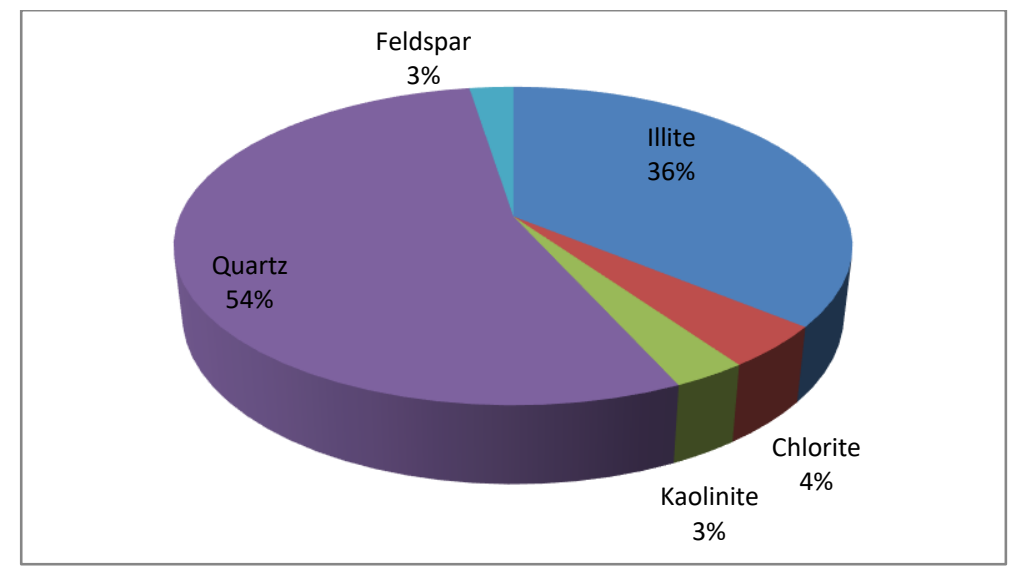

Fig. 2: Relative Abundance of Minerals in Finer Sediments.

\subsection{Kaolinite}

Kaolinite $\left[\mathrm{Al}_{2} \mathrm{SiO}_{5}(\mathrm{OH})_{4}\right]$ comprises $2.98 \%$ of the total mineral assemblage. The reflection at (001) plane corresponding to $7.08 \AA \AA^{2}$ is more intense than those from (020) and (110) planes.

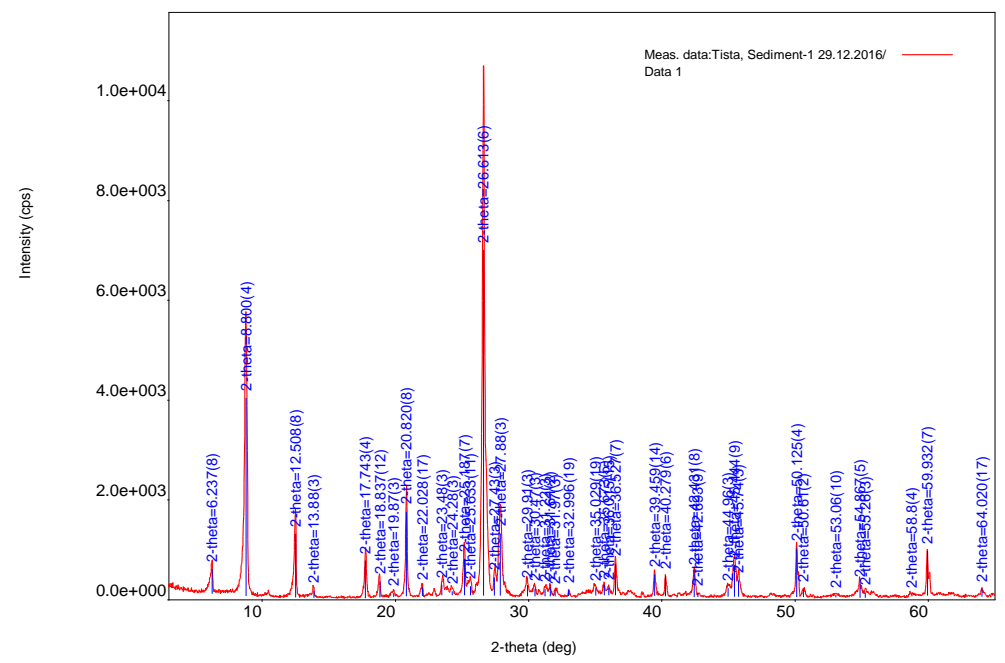

Fig. 3: XRD Pattern of Tista River Sediments at Station Pirgacha, Rangpur.

\subsection{Glauconite}

Glauconite $\left[(\mathrm{K}, \mathrm{Na})(\mathrm{Fe}, \mathrm{Al}, \mathrm{Mg})_{2}(\mathrm{Si}, \mathrm{Al})_{4} \mathrm{O}_{10}(\mathrm{OH})_{2}\right]$ is identified at basal reflections $10.011 \AA-10.043 \AA$. The peak at $4.973 \AA$ is stronger than the peak at $4.453 \AA$. Glauconite is reported from Mohipur and Chilmari. It is a mineral of mica group. Glauconite is considered a diagnostic mineral and indicative of continental shelf marine depositional environments with slow rates of accumulation (Birch et al., 1976). Glauconite forms under reducing conditions. The glauconite of the study area is of mechanical origin.

\section{Non-clay Mineral Assemblage}

\subsection{Quartz}

Quartz $\left(\mathrm{SiO}_{2}\right)$ is one of the major minerals that comprise 54 percent of the total rocks. Quartz is identified at basal reflection $4.24 \AA$. The peak at $3.339 \AA$ is stronger than the peak at $2.456 \AA$. $\alpha$-quartz is reported from Chilmari at basal reflections $4.257 \AA$. The amount of quartz decreases with increasing clay content of the sediments. 


\subsection{Feldspar}

Feldspars are identified at basal reflections 6.375-6.384A. The feldspar constitutes $2.50 \%$ of the total mineral of the study area. The amount of feldspar increases with increasing grain size of the sediments. Albite and anorthite are the main members of the feldspar family of the investigated area.

\subsection{Lavendulan}

Lavendulan $\left[\mathrm{Na}, \mathrm{Ca}, \mathrm{Cu}_{5}\left(\mathrm{AsO}_{4}\right)_{4} \mathrm{Cl} .5 \mathrm{H}_{2} \mathrm{O}\right]$ is identified at basal reflections 10.054-10.072 $\mathrm{A}$. The mineral is reported from Shutibari and Sundarganj. Lavendulan is an uncommon copper arsenate.

\subsection{Lepidolite}

Lepidolite $\left[\mathrm{K}\left(\mathrm{Al}_{0.62} \mathrm{Li} 0.38\right)_{2} \mathrm{Li} 0.92\left(\mathrm{Si}_{3.58} \mathrm{Al}_{0.42} \mathrm{O}_{10}\right)(\mathrm{OH})_{0.485}, \mathrm{~F}_{1.51}\right]$ is identified at basal reflection 3.883 $\mathrm{A}$. Lepidolite is a member of mica group. It is reported from Shutibari, Nilphamari. Lepidolite is the most common lithium-bearing mineral and might have derived from the weathering of granite pegmatites (Deer et al., 1979).

\subsection{Enstatite}

Enstatite $\left[\mathrm{MgSiO}_{3}\right]$ is identified at reflections $8.983 \AA$. Minor to trace amounts of enstatite is reported from Chilmari. Enstatite is a mineral which is magnesium end member of the pyroxene group. Enstatite might have deposited in the study by mechanical disintegration of basic igneous rocks like peridotite and pyroxenite.

\subsection{Sekaninaite}

Sekaninaite $\left[\mathrm{Fe}_{2} \mathrm{Al}_{4} \mathrm{Si}_{5} \mathrm{O}_{18}\right]$ is identified at basal reflection $8.428 \AA$. Sekaninaite is the iron rich analogue of cordierite. Minor to trace amounts of Sekaninaite are reported from Chilmari. Its occurrence is in the albite zone of pegmatite in granulites and gneisses.

\subsection{Ferrierite}

Ferrierite $\left[\mathrm{Ni}_{1.82}\left(\mathrm{Al}_{3.8} \mathrm{Si}_{32.2} \mathrm{O}_{72}\right)\left(\mathrm{H}_{2} \mathrm{O}\right)_{0.68}\right]$ is recognized at peak 2.01 $\mathrm{A}$. It is a mineral of zeolite group. Ferrierite typically occurs as an alteration mineral in basaltic rocks and in tuffaceous sediments. Ferrierite is found in the sediments of Pirgacha section of Tista River.

\section{Discussion}

\subsection{Clay minerals as a weathering proxy}

Clay minerals are formed as a direct result of weathering of primary rock material, and therefore, have the potential to provide information about the weathering history of rocks, as well as provenance. In the Tista river basin, the most dominant clay minerals are illite or muscovite, kaolinite and chlorite with trace amounts of illite/smectite interlayer clay. Illite might have been formed by the physical grinding of primary micaceous minerals or as secondary minerals from the chemical weathering of muscovite and feldspar minerals (Chaudhri and Singh, 2012). Some of the illite can be formed by the chemical alteration of kaolinite and/or smectites (Bjorlykke, 1998; Velde, 1995). clay (kaolinite, smectite) + cations $\left(\mathrm{K}^{+}\right)=$aluminosilicate (illite) + quartz + water.

In soils and rocks, many illitc clays seem to be mixtures of comminuted micas combined with more poorly-ordered $10 \AA ̊$ material (Wilson and Wilson, 2014).

Kaolinite minerals represent clays that have undergone a higher degree of alteration. Kaolinite is formed from intense chemical weathering of feldspars and micaceous minerals (biotite and muscovite) therefore, the presence of kaolinite is an indicative of significant alteration of sediments (Paolo, 2010). The presence of illite and kaolinite suggests their derivation from crystalline rocks containing feldspar and mica as well as from the pre-existing soils and sedimentary rocks (Chaudhri and Singh, 2012). Illite and chlorite are generally considered to be the products of physical erosion of low-grade metamorphic rocks with little chemical weathering and alteration (Alizai et al., 2012). Chlorite is commonly derived from the mechanical breakdown of low-grade metamorphic rocks that are found in the Himalayas through which the Tista River flows. Mixed layers may be formed as a result of chemical weathering of mafic igneous rocks. The presence of feldspar also suggests provenance of the sediments dominated by basic rocks in the source areas (Srivastava et al., 2013). The presence of illitekaolinite clay mineral assemblage is suggesting that the sediments were formed under humid, temperate and well drained conditions (Aftabuzzaman et al., 2013).

\subsection{Illite crystallinity (IC)}

Illite may be formed from either physical or chemical weathering processes; a useful tool in examining illite is the illite crystallinity (or the illite crystallization index, IC). The illite crystallization index is a proxy for how crystallized the illite in the studied clay samples. Hydrolization of illite expand the spacing between the layers and is enhance under condition of high rainfall and warmer temperature conditions, which lead to chemical weathering (Singer, 1984). A lower crystallinity index value indicates a smaller spacing between illite layers, which in turn indicative of a more crystallized, mechanically sourced illite. A higher crystallinity value indicated less-crystallized illite, and its derivation from diagenesis of primary minerals (Paolo, 2010).

The values of the illite crystallinity index varies from 0.228 to 0.345 , indicating that the illites present are relatively well crystallized and indicative of illite sources from the physical weathering of primary materials (Jaboyedoff et al., 2001). 


\section{Conclusion}

Illite or mica is the dominant clay minerals in the clay sediments of the floodplain of the Tista River. The other clay minerals are chlorite and kaolinite. The major non-clay minerals are quartz and feldspar. The accessory minerals of the studied sediments are lavendulan, lepidolite, enstatite, sekaninaite and ferrierite.

Illite and chlorite are generally considered to be the products of physical erosion of low-grade metamorphic rocks with little chemical weathering and alteration. Some of the illite can be formed by the chemical alteration of kaolinite and/or smectites. The quartz might have derived from acid igneous rocks and pre-existing sandstones. The presence of minerals like feldspar and enstatite are derived from basic igneous rocks and suggests admixture of different sources. Illite-kaolinite clay mineral assemblage indicates that the sediments were possibly formed under humid, temperate and well drained conditions.

The low values of illite crystallinity index indicating that the illites present are well crystallized and suggestive of illite sources from the mechanical weathering of primary rock materials.

\section{Conflict of interest statement}

Authors do not have any conflicts of interest.

\section{Acknowledgement}

The authors are grateful to Mr Istiaque Ahmed, Ex-Chairman, Petrobangla for providing kind permission to analyze the sediment samples in the Laboratory of BAPEX. The authors are also thankful to Ms Shahanaj Hossain, Manager (Geology), Laboratory Division of the Bangladesh Petroleum Exploration \& Production Company Limited (BAPEX) for her kind co-operation during the XRD-analyses of the sediments. The authors convey due thanks to Professor Dr. Golam Sabbir Sattar, Ex-Chairman and Professor Dr. Khondaker Emamul Haque, Chairman Department of Geology and Mining, University of Rajshahi, Bangladesh for arranging the research work. Special thanks to Mr. Sreekanta Saha for his kind help during the field work.

\section{References}

[1] Aftabuzzaman, M., Kabir, S., Islam, M. K. and Alam, M. S. 2013. Clay Mineralogy of the Pleistocene Soil Horizon in Barind Tract, Bangladesh. Journal of the Geological Society of India. 81(5): 677-684. https://doi.org/10.1007/s12594-013-0089-4.

[2] Alizai, A., Hillier, S., Clift, P. D., Giosan, L., Hurst, A., Vanlaningham, S. and Macklin, M. 2012. Clay Mineral Variations in Holocene Terrestrial Sediments from the Indus Basin. Quaternary Research. 77: 368-381. https://doi.org/10.1016/j.yqres.2012.01.008.

[3] Birch, G. F., Willis, J. P. and Rickard, R. S. 1976. An Electron Microprobe Study of Glauconites from the Continental Margin off the West Coast of South Africa. Marine Geology. 22: 271-283. https://doi.org/10.1016/0025-3227(76)90065-7.

[4] Bjorlykke, K. 1998. Clay Mineral Diagenesis in Sedimentary Basins-A Key to the Prediction of Rock Properties. Examples from the North Sea Basin. Clay Minerals. 33: 15-34. https://doi.org/10.1180/claymin.1998.033.1.03.

[5] Bullock, P., Fedoroff, N., Jomgerious, A., Stoops, G. and Tursine, T. 1985. Handbook of Soil Thin Section Description. Waine Research Publication, Wolverhampton, UK.

[6] Chakraborty, T. and Ghosh, P. 2010. The Geomorphology and Sedimentology of the Tista megafan, Darjeeling Himalaya: Implications for Megafan Building Processes. Geomorphology. 115: 252-266. https://doi.org/10.1016/j.geomorph.2009.06.035.

[7] Chaudhri, A. R. and Singh, M. 2012. Clay Minerals as Climate Change Indicators-A Case Study. American Journal of Climate Change. 1: 231-239. https://doi.org/10.4236/ajcc.2012.14020.

[8] Deer, W. A., Howie, R. A. and Zussman, J. 2001. Introduction to the Rock-forming Minerals. The English Language Book Society and Longman.

[9] Delvigne, J. E. 1998. Atlas of Micromorphology of Mineral Alteration and Weathering. Mineralogical Association of Canada, Ottawa.

[10] Heroy, D. C., Kuehl, S. A. and Goodbred, Jr. S. L. 2003. Mineralogy of the Ganges and Brahmaputra Rivers: Implications for River switching and Late Quaternary Climate Change. Sedimentary Geology. 155: 343-359. https://doi.org/10.1016/S0037-0738(02)00186-0.

[11] Jaboyedoff, M., Bussay, F., Kubler, B. and Thelen, Ph. 2001. Illite "Crystallinity" Revisited. Clays and Clay Minerals. 49: 156-167. https://doi.org/10.1346/CCMN.2001.0490205.

[12] Khan, A. A. and Rahman, T. 1992. An Analysis of the Gravity Field and Tectonic Evaluation of North Western Part of Bangladesh. Tectonophysics. 206: 301-364. https://doi.org/10.1016/0040-1951(92)90386-K.

[13] Meetei, L. I., Pattanayak, S. K., Bhaskar, A., Pandit, M. K. and Tandon, S. K. 2007. Climatic Imprints in Quaternary Valley fill Deposits of the middle Teesta Valley, Sikkim Himalaya. Quaternary International. 159(1): 32-46. https://doi.org/10.1016/j.quaint.2006.08.018.

[14] Moslehuddin, A. Z. M., Hussain, M. S., Saheed, S. M. and Egashira, K. 1999. Clay Mineral Distribution in Correspondence with Agroecological Regions of Bangladesh Soils. Clay Science. 11: 83-94.

[15] Moslehuddin, A. Z. M., Saheed, S. M. and Egashira, K. 1998. Mineralogical Approach to Alteration of Different River Sediments in Meghna Floodplains Soils Bangladesh. Clay Science. 10: 375-384.

[16] Mukhopadhyay, S. C. 1982. The Tista Basin. A case Study in Fluvial Geomorphology. New Delhi.

[17] Pal, D. K., Bhattacharyya, T., Sinha, R., Srivastava, P., Dasgupta, A. S., Chandran, P., Ray, S. K. and Nimje, A. 2012. Clay Minerals Record from Late Quaternary Drill Cores of the Ganga Plains and Their Implications for Provenance and Climate Change in the Himalayan Foreland. Paleogeography, Paleoclimatology, Paleoecology. 356-357: 27-37. https://doi.org/10.1016/j.palaeo.2011.05.009.

[18] Paolo, P. M. 2010. Provenance and Weathering of Holocene Ganges-Brahmaputra Sediments: Applications of Sr Geochemistry to Late Quaternary Delta Evolution. An Unpublished PhD Thesis, Marine and Atmospheric Science, Stony Brook University.

[19] Poch, R. M., Thomas, B. P., Fitzpatrick, R. W. and Merry, R. H. 2009. Micromorphological Evidence for Mineral Weathering Pathways in a Coastal Acid Sulphate Soil Sequence with Mediterranean-type Climate, South Australia. Australian Journal of Soil Research. 47: 403-422. https://doi.org/10.1071/SR07015.

[20] Rahman, M. A., Alam, M. J., Siddique, N. A. and Alam, A. M. S. 2013. Distribution of Arsenic with Iron, Manganese and Copper in Borehole Sediments of the River Tista and Jamuna. Dhaka University Journal of Science. 61(2): 207-210. https://doi.org/10.3329/dujs.v61i2.17072.

[21] Saha S., Roy M.K. and Reza, A.H.M.S. 2017. Textural Characteristics of the Sediments of the Tista River, Rangpur, Bangladesh. Journal of Life \& Earth Sciences.12: 73-79, 2017, JLES, RU.

[22] Saha, S., Roy, M. K., Ahmed, S. S. and Hossain, M. 2015. Clay Mineralogical Studies to Access Provenance in Estuarine Sequences: Hizla-GosairhatDamudya-Burirhat Branch of the Meghna Estuary, Bangladesh. 23RD Bangladesh Science Conference, Bangabandhu Sheikh Mujibur Rahman Agricultural University. 17-18 October 2015, p. 147.

[23] Samsuddin, A. H. M. and Abdullah, S. K. M. 1997. Geologic evolution of the Bengal Basin and Its Implication in Hydrocarbon Exploration in Bangladesh. Indian Journal of Geology. 69: 93-121. 
[24] Sarkar, D., Kabir, S. and Alam, A. K. M. K. 2009. Morphotectonics of the Eastern Part of the Tista Fan, Bangladesh. The IUP Journal of Earth Sciences. 3(4): 36-47.

[25] Singer, A. 1984. The Paleoclimatic Interpretation of Clay Minerals in Sediments-A Review. Earth Science Reviews. 21: $251-293$. https://doi.org/10.1016/0012-8252(84)90055-2.

[26] Srivastava, P., Aruche, M., Arya, A., Pal, D. K. and Singh, L. P. 2015. A Micromorphological Record of Contemporary and Relict Pedogenic Processes in Soils of Indo-Gangetic Plains: Implications for Mineral Weathering, Provenance and Climatic Changes. Earth Surface Processes and Landforms. DOI:10.1002/esp.3862. https://doi.org/10.1002/esp.3862.

[27] Srivastava, P., Banerjee, B., Aruche, M. and Ahmed, N. 2013. Clay Mineralogy of the Oldest Paleosols from the Himalayan Foreland: Implications of Diagenetic Overprinting and Paleoenvironments. Clay Research. 32 (1): 17-24.

[28] Srivastava, P., Rajak, M. K., Sinha, R., Pal, D. K. and Bhattacharyya, T. 2010. A High Resolution Micromorphological Record of the Late Quaternary Paleosols from Ganga-Yamuna Interfluve: Stratigraphic and Paleoclimatic Implications. Quaternary International. 227: 127-142. https://doi.org/10.1016/j.quaint.2010.02.019.

[29] Stoops, G. 2003. Guidelines for Analysis and Distribution of Soil and Regolith Thin Sections. WI: Soil science Society of America, Madison.

[30] Tennant, E. 2005. Late Quaternary Climate and Provenance Signals of the Ganges-Brahmaputra Delta Plain, Bangladesh. Honors Thesis, William and Mary, Williamsburg, VA.

[31] Velde, B. 1995. Origin and Mineralogy of Clays. Springer Verlag. https://doi.org/10.1007/978-3-662-12648-6.

[32] Wiejaczka, L., Bucala, A. and Sarkar, S. 2014. Human Role in Shaping the Hydromorphology of the Himalayan Rivers: Study of the Tista River in Darjeeling Himalaya. Current Science. 106(5): 717-724.

[33] Wilson, M. J. and Wilson, L. 2014. Clay Mineralogy and Shale Instability: An Alternative Conceptual Analysis. Clay Minerals. 49: 127-145. https://doi.org/10.1180/claymin.2014.049.2.01. 